\title{
THE TRAINING OF PUBLIC SPEAKING AND PROFESSIONAL ETHICS AT WORK FOR VOCATIONAL STUDENTS OF AL KAUTSAR, JAKARTA
}

\author{
Hayu LUSIANAWATY*, Mila Falma MASFUL \\ Sahid University, Indonesia \\ *hayulusianatemu@gmail.com, mila_falma@usahid.ac.id
}

\begin{abstract}
Seeing today's developments, young Indonesians are not just children who grow up and gain knowledge in the classroom. There are many ways so that they can upgrade their knowledge, for example by watching Youtube channels, taking online courses for free and so on. In addition to the methods mentioned above, schools can actually partner with other parties such as universities, where lecturers on campus provide training and tutorials related to appropriate materials for school children. Lecturers do not need to teach theoretical anymore but are able to provide training such as honing public speaking skills and understanding professional ethics at work. Why is it important for vocational students to learn this? No wonder there are still many young people who stutter and get nervous when speaking in front of many people. Then how will they face the world of work if they have graduated from school but this ability has not been honed? Apart from this, students also do not understand what the basic ethics are when working professionally. Therefore, this training is expected to be able to make students practice their public speaking skills in real terms, not only behind the training stage. Students are convinced to be able to deal with audiences or interlocutors well and confidently and of course demonstrate ethical values when working in an agency, both with the environment within the company and outside. This training is part of community service activities from Lecturers of the Faculty of Communication, Sahid University, Jakarta. The activity was held by online in August 2021.
\end{abstract}

Keywords: Communication, Public Speaking, Professional Ethics

\section{BACKGROUND}

Communication is a very important element in modern life today. Communication made by someone will influence decisions, form networking, become a motivation and can cause changes in society. Without good communication skills, one's progress will be hampered in the environment where one is located, such as at school, on campus or in the office. And will affect interactions in the world of work, both between fellow co-workers to interactions with company clients.

During this pandemic period, we can see state leaders, ministers, heads of agencies delivering speeches on the development and evaluation of covid19. Likewise, artists, influencers, ambassadors, master ceremonies, advertisers and so on help campaign for the implementation of Health protocols in conventional media and digital media. What is conveyed is very important things that must be known by all Indonesian people and the world. In conveying the messages verbally, the communicators speak in a structured and regular manner accompanied by a movement (gesture) which aims to make the message to be conveyed to the public clearly accepted by the audience. Likewise, influencers, for example, who deliver messages for charity activities, campaigns at home, or in conveying messages on products/services offered, must really master the language, words and master product knowledge in the advertisements submitted so that the public can understand and make a purchase. Likewise, for a master of ceremonies or MC who is in charge of hosting the event, it is hoped that the message conveyed can be understood by the public so that the event that is delivered runs smoothly.

Public speaking is one way out of communication, but speaking in front of the public is also the thing that most people fear because of anxiety in public speaking and a fear of its own, especially for high school students. Basically, these students are future leaders of the nation, community leaders and leaders in organizations where they will work later. Special skills are needed from an early age, but this public speaking skill can be honed to the maximum without fear and anxiety. Not only speaking in front of the class or at the school level, another problem for high school students is that they will become school representatives in extra-curricular activities outside of school such as speech competitions, art performances, charity activities, and other activities to represent the school including for readiness students enter college and work careers. Students and students of SMK Al-Kautsar South Jakarta have not had enough achievements to be proud of this is due to a lack of understanding about how to speak in public and do not understand how to present a work in front of an audience.

\section{Theoretical Framework}

Bahar (2016) reveals that speaking to improve the quality of existence is not just talking, but talking that is interesting, informative, entertaining and influencing. Public speaking does not only focus on spoken words but also body language or often called non-verbal language, because not all elements of communication can be explained in words. There are some things that can only be conveyed with body language. Therefore, the use of body language in public speaking is needed (Adha, 2016).

In Nieke Monika (2017) states the latest rhetorical figure James A. Winans in his book "public speaking" (1917) which uses the psychology of William James and E.B Tichener that a person's actions are determined by the presence of attention. In this case, Winans defines persuasion as a process of growing attention. The importance of arousing emotions through psychological 
motives such as self-interest, social obligations and religious obligations.

The benefits of public speaking skills described in Nieke (2017) are: 1. Developing ourselves personally, 2. Influencing the world around us, and 3. Increasing careers. In addition, the benefit of public speaking for high school students is to increase their portfolio in reaching their goals.

Of course, another thing that supports a beginner when entering the world of work is not only being able to speak well in public but also applying professional ethical values appropriately. As said by K. Bartens (2020: 3) If we want to analyze the understanding of the profession, the first thing that can be approved is that the profession belongs to the category of work or occupation, because occupation means daily work that keeps a person busy.

This PKM was held virtually and the target participants were SMK Al Kautsar, South Jakarta. Where the Kautsar Navy Vocational School was established in 1990 which equips its students with knowledge and moral skills to be competent in: 1). Develop and apply managerial skills, 2). Develop and implement financial management capabilities and 3). Develop and apply network technology capabilities (smkalkautsarkbybaru.sch.id).

\section{METHOD}

The method used in this PKM is as follows:

The first is the Lecture session, which is the delivery of material through a 45-minute zoom meeting. The material is presented in the form of power points which are shared in the screen zoom meeting. After the lecture continued with the second session, Q\&A and discussion for 45 minutes, at this time there were a lot of questions and responses from the participants. During the discussion, there was a change in the attitude of the participants, which was initially rigid, the screen was visible, then during the discussion there was feedback between the sender and the recipient of the message.

The third stage is a 20-minute Solutions session, where in this session the speaker conveys insights and answers to participants related to techniques and how to communicate well in public. That in general communication consists of two types of communication, namely verbal and non-verbal.

In addition to the number of audiences, public speaking is distinguished in three ways:

1. Structured Public Speaking

2. Public Speaking which requires a formal language

3. Public Speaking requires a different delivery method.

The fourth stage is Practice for 60 minutes, where students and participants are provided with how to stand, how to use gestures properly, control vocals, and perform in public speaking and are shown examples through several videos. For example (in video form) giving speeches, master ceremonies and presentation skills. Furthermore, several selected participants were asked to practice directly for 5-10 minutes. The best participants get appreciation from the audience and resource persons. Furthermore, in the fifth session, namely Evaluation for 15 minutes, where the resource persons and participants provided responses and feedback related to the implementation of this public speaking training activity.

The exploration of carrying out this activity has been started since early 2020 but because at that time Covid began to occur, coordination with the previous partner, namely the Sunday Market Vocational School, had stopped. In addition, at the SMK there was also a change of Principal which made it more difficult for us to continue coordination. For this reason, in early 2021 we began to look for other SMKs by submitting activity proposals. SMK AL Kautsar is our partner for this service activity. After communicating with the school, the planning of this activity is as follows:

1. Define the target audience

a. The PKM team conducted an assessment of one school where the party had established a good relationship with the PKM team.

b. SMK AL Kautsar is interested in our proposed activity because the training that we will provide is very useful for grade 12 students because they will finish school and will face the outside world.

c. 12th grade SMK students consist of 80 people

2. Determine the speaker

a. The persons who will provide the training consist of two lecturers from the Faculty of Communication, Sahid University, Jakarta, namely Dr. Hayu and Mrs. Mila Falma.

b. Persons are people who are competent in their fields, namely understanding how to do good public speaking and professional ethics at work.

3. Implementation of activities

a. Held on Monday $2^{\text {nd }}$ August 2021, with two sessions, namely:

i. Session 1: 10.00 - 12.00: Public Speaking for beginners

ii. Session 2: 12.30 - 14.30: Professional Ethics at work

b. Each session will be filled with material briefing and hands-on practice. In addition, there will be a question-and-answer session and a quiz.

4. Tools used

This training is conducted online, students are asked to use their own laptops or computers. Likewise with the speakers. In addition, there must be a stable internet network available.

\section{RESULT AND DISCUSSION}

\section{Public Speaking for Beginners}

PKM activities at Al-KAutsar Vocational School in South Jakarta will be held on August 2, 2021, starting at $10.00 \mathrm{PM}$. The number of participants who attended the zoom meeting reached almost 80 participants from 
class VII to class IX. This basic public speaking and professional ethics training activity runs from morning to evening consisting of five sessions.

The activity begins with a presentation by the author (the first resource person) for approximately 20 minutes and continues with the second resource person for 25 minutes. The material presented is presented in a relaxed manner and in light language so that it is easily understood by the participants. The author gives a lecture related to public speaking. In the first slide, the author describes the purpose of communication, namely to provide education (to educate), to provide information (to inform) to the public, second to persuasion (to persuade) and the third as an entertainment function (to entertain).

The next material explains the definition and use of public speaking, where the benefits of Public Speaking (Hamilton, 2003) in Kulsum (2014) are:

1. To develop personality, where currently many companies ask prospective workers to be able to present ideas and ideas as outlined in the form of a proposal. During this presentation, speaking and intonation skills as well as language selection are very important so that the company leadership can understand and accept the message conveyed by the prospective employee. On the other hand, a professional and ethical gesture and appearance will give a good impression to the company's leadership.

2. Influencing the world around us, that the ability to influence others around us will produce changes in a group. The ability of public speaking in raising Independence Day funds in the surrounding environment is needed so that the required funds can be collected and useful.

3. Improving careers, in this case including influencing leaders to improve our work, supported by speaking and persuasion skills, leaders will see us as someone who has high credibility, is capable and reliable.

The next material is related to self-confidence when doing public speaking, characteristics of public speaking, the art of speaking, the art of delivering a speech, the art of being an MC, and how to do persuasion. Then there is also material about audience analysis in public speaking and the use of correct words and sentences in public speaking. After the material stage is complete, participants are given time to ask questions or respond to the material that has been delivered. The participants were very enthusiastic about asking questions, as seen from the many questions in the chat column and those who asked directly. The participants' questions were more about how to increase self-confidence and how to speak fluently, as well as questions such as Techniques for being a successful MC.

After the question-and-answer session was continued with a practice session, it is unfortunate that this training activity could not directly meet and meet the participants because it was still in the pandemic and PPKM period, so the practice carried out was felt by the participants to be lacking. Because all participants should practice one treatment according to the theme, they are interested in. Participants and teachers hope that public speaking and professional ethics training activities can be continued to the next stage and are expected to work together in the form of apprentice students and apprentice teachers at Sahid University. On the other hand, it is hoped that there will be further activities in the form of seminars and training on other communication topics, such as marketing communications, digital communications, business communications, etc.

\section{Professional Ethics at Work}

In fact, the basic skills that must be possessed by someone when they want to master the world of work are not only the ability to speak in front of many people. Ability and behavior become the right combination to face the world of work in the future. Good behavior and personality will be reflected when someone is dealing with other people. For this reason, in professional activities working in a company, ethics is a key to success.

As stated by Mochamad Raka Pratama, Pupung Purnamasari and Mey Maemunah, (2019) in the online journal Karyailmiah.unisba.ac.id, it is stated that the Effect of Professional Ethics on Auditor Performance The results of the research show that professional ethical attitudes have a significant positive effect on auditor performance

Professional ethics is a form of one's integrity to the organization. Greenstone (2018) states that one's professional ethics is indicated by: (1) one's awareness of the applicable rules of agreed values; (2) a person's willingness to engage in dialogue with various entities in the organization; and (3) ethics will be taken into consideration in the interaction between leaders and fellow members of the organization. Professional ethics must be adhered to by everyone in their work, because professional ethics are ethical considerations and professional guidelines that are relevant in every profession (Rodríguez and Juričić, (2018). So it can be understood that every profession certainly has professional ethics that are different from other professions. However, there are some universally applicable professional ethics, such as: responsibility; integrity; objectivity; and maintain confidentiality (Sultoni, Imam Gunawan, Dika Novita Sari, 2018).

For this reason, the writing team wishes to provide professional work ethics training for students at SMK Al Kautsar Jakarta. Seeing job opportunities after they graduate, this activity needs to be given and continue to be honed by students so that they are more qualified in carrying out their work.

1. In the second session, the training was conducted online, namely through a zoom meeting. The meeting lasted two hours on the day of Monday, $2^{\text {nd }}$ August 2021 The materials provided are:

a. Explain the code of ethics of professional ethics. Usually, each profession will have written standards 
of ethical values that must be carried out properly.

b. good behavior and ethics are aimed at superiors in the office, fellow co-workers, clients and the wider community. This measure of behavior will not be the same. For this reason, it is necessary to explain how ethics must be applied.

c. Practicing how to gesture, how to speak and others when working.

2. The training went very smoothly even though sometimes there were slight disturbances such as a sudden network delay. This activity is also interspersed with light quizzes so that the event is not monotonous and makes students bored

3. The trainees consist of 80 class 12 . Students are very enthusiastic about participating in this activity because some of them will most likely choose to apply for jobs when they graduate. And the provision of this training can add to their experience.

At this online meeting, the writing team concluded this series of events with satisfaction. With a happy heart, finally the implementation can go well without being constrained by serious problems.

\section{Results obtained during training}

It is undeniable that making an activity that involves many people is not easy but because the team and the school have coordinated for almost 5 months, the activity can be carried out with the target participants in accordance with the training. Training activities must be carried out online considering government regulations that do not allow crowds to be held due to the worsening pandemic, where initially the activities will be carried out face-to-face. There are 2 trainings that are followed by the students, namely how to improve the ability to speak in public or many people and apply professional ethical values in working in a company. The team always coordinates to design the right material and is easy to understand by students because after all, the trainees are not students who are used to quite heavy theoretical. During the training the students were also asked to directly make assignments according to the material and practice the parts that need to be displayed such as telling personal experiences in front of other participants and exemplifying good gestures and behavior when working. Of course, with this four-hour training, quite satisfactory results were obtained, as it could be seen that the students were not shy about asking questions and taking the initiative to practice the assigned tasks.

However, for some other students the results of this training were not very satisfactory because there were several obstacles such as the equipment used was sometimes incomplete. In addition, it is difficult to monitor participants during the training because some still turn off the camera when training and learning are being given. And this is the disadvantage of holding online events so that it is hoped that in the future training will be provided face-to-face.

\section{CONCLUSION}

Overall, the event to increase knowledge and skills of public speaking and professional ethics among students of SMK Al Kautsar went well. Participants were very enthusiastic, proactive and enthusiastic to appear speaking even in front of the zoom meeting screen. It is hoped that further activities will be held every semester at the school. At the end of the event, it was closed with a group photo and giving souvenirs to all participants and giving prizes to the best participants and questioners.

\section{ACKNOWLEDGMENTS}

We would like to thank Sahid University Jakarta as an institution that has provided the opportunity and space to support this service to be carried out properly. Second, the partner, namely SMK Al Kautsar, who made us participants to share experiences and knowledge with grade 12 students. Next, we would like to thank the Faculty of Communication Studies and other lecturers for their support and input for this service.

\section{REFERENCES}

Adha, (2016), Panduan Mudah public Speaking. Yogyakarta. Komunika

Ajzen Icek (2014), Persuasive Communication Thory in Social Psychology. https://www.researchgate.net/ publication/255661892

Bahar,P (2016) Seni membawakan Pidato dan MC, Yogyakarta: Chivita Books

Bertens, K. (2020) Etika Profesi. Gamedia Pustaka Utama, Indonesia

Girsang, Lasmery (2018), Public Speaking sebagai bagian dari komunikasi efektif. Jurnal Pengabdian dan Kewirausahaan vol.2, No.2. 811-85.2018. jurnal. ubm.ac.id

Roswita, Farid (2019) Belajar Public Speaking Sebagai Komunikasi yang Efektif. Jurnal bakti Masyarakat Indonesia Vo.2, No. 1, Mei 2019, Hal 117-122. ISSN 2621-0398.

Nieke Monika Kulsum (2017) Modul Public Speaking, Universitas Nasional, Jakarta.

http://karyailmiah.unisba.ac.id/index.php/akuntansi/ article/view/16212/pdf\# Diakses pada hari Minggu, 1 Agustus 2021 pukul 10.30 WIB

JAMP: Jurnal Adminitrasi dan Manajemen Pendidikan Volume 1 Nomor 3 September 2018. Hal 279-283 